\title{
Commercial Benefits of International Cooperation of Cyber Lawyers
}

Viktor Fersht, International Smart University, Russia

Qin Yuxuan, International Smart University, China

International cyber mediation is currently the most demanded service in the legal services market. The growth of cyber-attacks on the Internet, a large number of scams with cryptocurrency, falsification of products, goods and services sold on the Internet, as well as theft of money from credit cards and from online accounts of Internet users - all this requires the help of cyber lawyers.

Since the Asia-Pacific region is the most developed and most populous Internet space in the world, the market for Internet mediator services should be the most profitable.

Keywords: cyber lawyer, cyber mediator, cyber security, internet commerce, cryptocurrency, Asia-Pacific region.

\section{International Cyber Lawyers}

Cyber attorneys are lawyers who have received additional IT education and participate in the resolution of disputes over conflicts that have occurred on the Internet in court sessions.

Cyber mediators are lawyers who have received additional IT education and participate in the resolution of disputes on conflicts that have occurred in the Internet space in pre-trial settlement.

Cyberspace is a cross-border area. Therefore, cyber jurisprudence is possible only with international cooperation of cyber lawyers.

For example, a person living in Korea buys an item from a Chinese online store and does not receive the item. However, he does not have the opportunity to contact a mediator in China (another language, ignorance of the laws of another country, lack of contacts, etc.). The settlement of the dispute is possible only when the victim contacts the Korean mediator, who in turn will contact his Chinese partner and they will jointly resolve the conflict.

International cyber lawyers are currently the most expensive legal services in the world. Due to the growing popularity of cryptocurrency and online trading at an avalanche speed, over the past two years, the number of disputes and conflicts on the Internet has increased hundreds of times. However, due to the cross-border nature of the Internet, only international cyber-mediators who have partners in foreign countries can resolve these conflicts. So far there are few such specialists in the world and they are in great demand. Therefore, the average payment for the services of cyber lawyers exceeds the rates of ordinary lawyers by about two to three times (depending on the country).

International organizations dealing with legal mediation on the Internet United Nations - World Intellectual Property Organization (WIPO), International Telecommunication Union (ITU), Interpol, International Association of IT Lawyers (IAITL), American Bar Association Cybersecurity Legal Task Force, 
World Jurist Association, World Trade Organization, Asian Privacy Scholars Network, Korea University Cyber Law Center.

\section{Cyber mediation and cyber advocacy services market Crypto Crime}

According to a statistical analysis by IBM Watson, every seventh cryptowallet is hacked in the world, cryptocurrency is stolen at every eighth cryptoexchange, 85 percent of ICOs in the world are fictitious or not implemented after receiving funds.

People who have suffered from crypto crimes living in different countries can turn to an international crypto lawyer and crypto mediators to legally resolve disputes with Internet scammers who have defrauded them.

Crypto disputes can be resolved both in courts at the location of the criminals or international arbitration courts, and in pre-trial order.

\section{Cyber commerce}

Every tenth purchase on the worldwide Internet does not come to the buyer or comes with defects or with a substitution of goods.

These are not only online stores, but also trade for private ads, the provision of non-existent or low-quality services on the Internet.

The buyer cannot protect his interests without international mediators.

Cyber trade disputes can be resolved by cyber mediators who have direct contracts with chain stores, as well as with international cyber detective agencies.

\section{Cyber counterfeits}

On the Internet, every fifth food product, every fourth medicine, every third luxury item and work of art offered to customers is fake. Interpol conducts Panageya operations annually to identify counterfeit manufacturers.

Cyber mediators and cyber lawyers can help their clients work with Interpol to resolve conflicts with suppliers of counterfeit goods.

\section{Online financial crimes}

Online financial crime is the most popular topic for cyber criminals due to its high profitability in a short time.

Hacking or theft of online accounts or card information by cyber criminals, as well as the dishonest performance of their duties by banks and telephone companies, are not amenable to statistical analysis. Presumably, the victims of such crimes in the world are every second user of cyber financial transactions.

Interpol and various $\mathrm{UN}$ agencies have created dedicated internet platforms for victims of cyber financial crimes. International cyber mediators can actively help their clients resolve these conflicts through collaboration with Interpol and the UN. 
Every second information on the Internet becomes the object of plagiarism or misappropriation without the consent of the author.

UN agency - The World Intellectual Property Organization (WIPO) offers cyber mediators and cyber lawyers a variety of options for protecting intellectual property rights on the Internet.

Internet harassment

According to Pew Research, about 41 percent of internet users have been victims of online harassment.

1 in 5 citizens have experienced severe forms of harassment, such as physical threats, sexual harassment or harassment.

Harassment is especially common among young people. More than 65 percent of children between the ages of 18 and 29 have been victims of harassment. Almost half of people aged 30-49 are harassed online.

Cyber mediators through a cyber detective agency can find the persecutor and solve problems with him with the help of law enforcement agencies.

\section{Online defamation}

Almost all famous people are subject to defamation on social networks and online publications. Every year, courts around the world receive libel statements from about 1 million people.

More than half of them are resolved by mediators in a pre-trial order.

\section{Cyber Insurances and Cyber Mediation}

Insurance companies are willing to include the services of mediators and lawyers in their cyber insurance policies in case of claims.

Almost all insurance companies in the world insure Internet safety. But none of them is able to work in foreign countries, due to the difference in jurisdictions and the impossibility of confirming the violation of the insurance conditions abroad.

International cyber mediators and cyber lawyers must team up in one international insurance company to operate in all countries of the world.

\section{Cyber detective agencies}

There are more than 500 thousand detective agencies in the world that are engaged in private investigations of crimes on the Internet.

There are also large international investigative companies that work on orders from states and transnational companies.

Most of them are partners of Interpol and the UN. For example, Kaspersky Lab. and Group IB, which exposed Internet attacks and bank robberies by the North Korean government hacker group Lazarus.

International cyber mediators and cyber lawyers need their own global international cyber detective company that can work for small and medium businesses and private clients. 


\section{Cyber Mediator and Crypto Lawyer Training}

Cyber lawyers should be trained in programs that provide the ability to provide mediation and advocacy services in any country in the world.

Training can be conducted online, remotely and in person.

Universities in the Asia-Pacific region can participate in this international training program for their students and mediators-advocates wishing to specialize in cyber security.

Currently, in the Asia-Pacific region, the most in-demand training programs for cyber lawyers are at Korea University, Honkoga University, Moscow State University of Technology and Management, Vladivostok State University of Economics and Service.

How to organize international commercial cooperation between cyber lawyers and cyber mediators in the Asia-Pacific region?

For successful cooperation between cyber mediators and cyber lawyers, it is possible to use the experience of European countries and create an international Internet platform for interaction of cyber mediators, cyber lawyers with clients of APEC countries.

It is necessary to register the platform with Interpol, the UN agencies: the World Intellectual Property Organization (WIPO) and the International Telecommunication Union, as well as APEC.

Then apply for international grants to fund the activities of an international Internet platform for interaction of cyber mediators, cyber lawyers with clients of APEC countries.

An example of the MEDICYS internet platform

for interaction between cyber mediators and cyber lawyers in Europe

Platform website: http://www.huissier-justice.fr/en/news.aspx?id=270

The National Court of Justice has established a Mediation and Cyber Services Center for the pre-trial settlement of disputes and conflicts.

The center was created in partnership with the Cyber Justice Laboratory of the University of Montreal, a global expert in the field of e-justice.

It is a unique internet platform in Europe that offers an alternative and reliable way to resolve conflicts.

The number of commercial disputes among consumers is constantly growing in society, but conflicting parties are increasingly abandoning courts and therefore not receiving compensation.

Several factors explain this trend: the cost and length of the procedures, inconsistencies between the litigation and the nature of the conflict ... European consumers and professionals can now access an online platform to resolve out-of-court disputes arising from their online transactions.

The platform has the following strengths: - a digital platform capable of offering a comprehensive solution to various disputes (mediation $100 \%$ online, videoconference or in the office); - Guarantee of a process supervised by a civil servant specially trained in the field of mediation. 
"The platform has already attracted a number of professionals to participate, such as the French Federation of Buildings (FFB), which is developing a special module on it "Building Litigation".

\section{Bibliography}

1. Jin L.and Robey D. Explaining Cybermediation: An Organizational Analysi $\mathrm{s}$ of Electronic Retailing. International Journal of Electronic Commerce, no. 3(4), 1999 pp. 47-65.

2. Les Killion. Cybermediation in the Tourism and Travel Industries, SelfService in the Internet Age, 2008

3. Llewellyn Joseph Gibbons, Robin M. Kennedy Jon Michael Gibbs.

Frontiers of Law: The Internet and Cyberspace: Cyber mediation communications Medium Massaging the Message, New Mexico Law Review Winter, 2002

4. Goodmen J.W.The Pros and Cons of Online Dispute Resolution: an Assessment of Cyber-Mediation Websites Duke Law and Technology Review, 2003

5. Kenneth Rashbaum. Growing Demand For Mediation Of Data Breach Disputes, Law360, July 17, 2017

6. Bailey, Joseph P., and Bakos, Yannis. An exploratory study of the emerging role of electronic intermediaries. International Journal of Electronic Commerce, 1, 3 (Spring 1997), 7-20.

7. Bakos, Yannis. The emerging role of electronic marketplaces on the Internet. Communication of the ACM, 41, 8 (August 1998), 35-42.

8. Benjamin, Robert, and Wigand, Rolf. Electronic markets and virtual value chains on the information superhighway. Sloan Management Review, 36, 2 (Winter 1995), 62- 72.

9. Burt, Ronald S.. Structural Holes, The Social Structure of Competition. Cambridge Massachusetts: Harvard University Press, 1992.

10. Golfinopoulos, George, and Talbot, Jean. Commercial intermediaries on the Internet: towards a new perspective. Proceedings of III rd International Conference on Management and Networked Enterprises. St-Amant, Gilles, and Amani, Mokthar (ed.). Montreal, Quebec: 1998, 410-429.

11.Green, Heather, and Browder, Seanna. Online merchants--cyberspace winners: how they did it. Business Week, (June 22, 1998), 154-160.

12.Harvard Business School, Virtual vineyards, 9-396-264, (April 8, 1996).

13.Hof, Robert D., and McWilliams, Gary. The 'click here' economy. Business Week, (June 22, 1998), 122-128.

14. Machlis, Sharon. Barnesandnoble.com revamp aims at Amazon.com. Computerworld Online News, (October 23, 1998). 30

15.Negroponte, N.. The future of retail. Wired, (July 1998), 184.

16. Nonaka, I.. A dynamic theory of organizational knowledge creation. Organization Science, 5, 1 (February 1994), 14-37.

17.Perrow, Charles. Complex Organizations, A Critical Essay. New York: McGrawHill, Inc., 1993. 
18.Sager, Ira, and Green, Heather. So where are all the bargains? Business Week, (June 22, 1998), 154-160.

19.Sarkar, M. B., Butler, B., and Steinfield, C.. Intermediaries and cybermediaries: a continuing role for mediating players in the electronic marketplace. Journal of Computer-Mediated Communication, 1, 3 (December 1995).

20. Scott, W. Richard. Institutions and Organizations. Thousand Oaks: SAGE Publications, 1995.

21.Steinfield, C., Kraut, R., and Plummer, A.. The impact of interorganizational networks on buyer-seller relationships. Journal of Computer-Mediated Communication, 1, 3 (December 1995).

22.Suchman, M.C.. Managing legitimacy: strategic and institutional approaches. Academy of Management Review, 20 (1995), 571-610.

23.Tapscott, Don. The Digital Economy. New York: McGraw-Hill, 1995.

24.Bailey, J. P. \& Bakos, J. Y. (1997). An Exploratory Study of the Emerging Role of Electronic Intermediaries. International Journal of Electronic Commerce 1(3): 7-20.

25.Benjamin, R. \& Wigand, R. (1995). Electronic Markets and Virtual Value Chains on the Information Superhighway. Sloan Management Review 36(2) (winter)): 62-72.

26.Bieger, T. \& Laesser, C. (2002). Market Segmentation by Motivation: The Case of Switzerland. Journal of Travel Research 41(1): 68-76.

27.Doty, D. H. \& Glick, W. H. (1994). Typologies as a Unique Form of Theory Building: Toward Improved Understanding and Modeling. Academy of Management Review 19(2): 230-251. E-businessW@tch. (2006). ICT and eBusiness in the Tourism Industry (Sector Report No. 8/2006). Brussels, Belgium: European Commission.

28. Giaglis, G. M., Klein, S. \& O'Keefe, R. M. (2002). The Role of Intermediaries in Electronic Marketplaces: Developing a Contingency Model. Information Systems Journal 12(3): 231-246.

29.Gordijn, J. \& Akkermans, H. (2003). Value Based Requirements Engineering: Exploring Innovative e-Commerce Ideas. Requirements Engineering Journal 8(2): 114-134.

30.Klein, S. \& Teubner, R. A. (2000). Web-based Procurement: New Roles for Intermediaries. Information Systems Frontiers 2(1): 19-30.

31.Lindemann, M. A. \& Schmid, B. F. (1999). Framework for Specifying, Building, and Operating Electronic Markets. International Journal of Electronic Commerce 3(2): 7-21.

32. Malone, T. W., Yates, J. \& Benjamin, R. (1987). Electronic Markets and Electronic Hierarchies. Communications of the ACM 30(6): 484-497.

33.Mayr, T. \& Zins, A. H. (2009). Acceptance of Online vs. Traditional Travel Agencies. Anatolia: An International Journal of Tourism and Hospitality Research 20(1): 164-177. 
34.Müller-Lankenau, C. (2007). Multikanalstrategien im stationären Einzelhandel. Eine empirische Untersuchung in der

Kommunikationsbranche. PhD-thesis, University of Munster, Germany.

35. Osterwalder, A., Pigneur, Y. \& Tucci, C. L. (2005). Clarifying Business

Models: Origins, Present, and Future of the Concept. Communications of the Association for Information Systems 16(1): Online Publication.

36.Rensmann, B. \& Klein, S. (2011). Sarkar, Butler \& Steinfield (1995) "Intermediaries and Cybermediaries" Revisited: A Review and Identification of Future Research Directions for Intermediaries in Electronic Markets. Proceedings of the 24th Bled eConference, Bled, Slovenia.

37.Sarkar, M. B., Butler, B. \& Steinfield, C. (1995). Intermediaries and Cybermediaries: A Continuing Role for Mediating Players in the Electronic Marketplace. Journal of Computer-Mediated Communication 1(3): Online Publication. 